\title{
Not Making the Grade: A Narrative Inquiry Into Timmy's Experiences With the Mandated Curriculum
}

\author{
Sonia T. Houle \\ University of Alberta
}

\section{Author Note}

I wish to thank Jean Clandinin and Claire Desrochers for their ongoing support in writing this manuscript.

Correspondence concerning this article should be addressed to Sonia T. Houle, University of Alberta, 633 Education Building South, Edmonton, Alberta T6G 2 G5. Telephone: (780) 492-7770. Email: sonia.houle@ualberta.ca

\begin{abstract}
This research draws on the experiences of a Grade 1 delayed reader, his parents, and his teachers, to show his lived curriculum across his home and school contexts. This narrative inquiry is situated in the literature of curriculum studies, in the notions of the lived curriculum and curriculum-making. Field texts include field notes from the classrooms, transcripts of conversations with the child, his parents, and his teachers. For this paper, I illustrate the child's experiences at the end of Grade 1, among the tensions created between the lived curriculum of a struggling reader, and the expectations of the mandated curriculum, which are shaped by institutional and sociocultural narratives. My goal is to provide insight into making curriculum in schools that accounts for the lived curricula of all children.
\end{abstract}

Keywords: lived curriculum; narrative inquiry; curriculum-making 


\section{Not Making the Grade: A Narrative Inquiry Into Timmy’s Experiences With the Mandated Curriculum}

When I taught Grade 1, most children learned to read during the school year. I remember the excitement in children's eyes as they realized they could read. They experienced it as a big stepping stone, and I experienced joy watching them. I also remember Lucas's worried eyes as he tried to read like his peers, but was unable to. I was perplexed. How was this 6-year-old child experiencing school while he struggled to read like his peers? My wonders about the experiences of children who do not learn to read in Grade 1 led me to this study.

There is a dominant narrative that children should learn to read in Grade 1; it is firmly established in Canadian schools and in children's and families' stories. ${ }^{1}$ However, contrary to the institutional and sociocultural narratives, children do not always learn to read in Grade 1, and this is often perceived as problematic. There is an impressive amount of work devoted to searching for best practices in the teaching of reading. However, I wanted to understand the experiences of children who struggle to learn to read, as well as their parents' and teachers' experiences of being next to them. In this multiperspectival inquiry, I am interested in the tensions created between the lived curriculum of a struggling reader, ${ }^{2}$ and the expectations of the mandated curriculum, which are shaped by institutional and sociocultural narratives.

\section{Theoretical Perspectives}

\section{Education - Life - Experience}

John Dewey’s (1938) philosophy influenced the shaping of my research puzzle as he drew attention to education as life and life as experience and as forever changing and relational. The relational nature of Dewey's philosophy resonated with how I understand learning. His emphasis on the continuity of experience, how "every experience lives on in further experiences" (Dewey, 1938, p. 27), helped me attend to past lived experiences and how they influence present and future experiences. While there is a general sense that education leads into the future, Dewey (1938) insisted that education be for today, not a preparation for the future: "We always live at the time we live and not at some other time, and only by extracting at each present time the full meaning of each present experience are we prepared for doing the same thing in the future" (p. 49). An educative experience today should prepare us for tomorrow. Delayed readers may experience reading as a struggle, and Dewey triggered my interest in studying their experiences.

\section{A Teacher's New Understanding of Curriculum and Curriculum Making}

My wonders about struggling readers' experiences in school and a Deweyan perspective on education led me to Connelly and Clandinin's (1988) work on curriculum making. They, along with Aoki (1993), introduced new ways of thinking about curriculum. For many teachers, and for me, the term "curriculum" referred to the thick document found in classrooms, consulted when planning. It is written by professionals and passed on to school boards and teachers to be enacted through learning activities. Even though I tried to recognize and consider the uniqueness of each student I taught, reading Aoki awakened me to a lived curriculum, particular to each student and teacher. Recognizing "there are many lived curricula, as many as there are self and students” (Aoki, 1993, p. 258), helped me re-imagine making curriculum.

Reading Connelly and Clandinin (1988) allowed me to understand that from day one, I had been making curriculum in my classes; I was just unaware that I was. I believe how I made curriculum then was limited by my interpretation of the mandated curriculum (Alberta 
Education, 2000) that I had considered was the only legitimate curriculum. ${ }^{\underline{3}}$ I felt trapped and directed by the sacred stories of school that impose a specific curriculum and did not understand there were multiple curricula in my classroom: the mandated as well as numerous lived curricula $^{4}$ While I did not make the mandated curriculum, the students and I were co-composing the lived curricula. ${ }^{-}$It is in that multiplicity of curricula (Aoki, 1993), that I am inspired to make curriculum with re-imagined possibilities.

Clandinin et al. (2006) point out that Schwab’s (1970) four curriculum commonplaces need to be attended to "in order to understand the negotiation of curriculum" in curriculum making: teacher, learner, subject matter, and milieu (p. 172). The lives of teachers along with the lives of children (learners) meet in schools and classrooms (milieus) around a subject matter. From this complex intersection where the lived experiences of teachers and students meet, emerges the lived curriculum, the focus of this manuscript.

In my experience, the lived curriculum is not commonly and officially addressed in schools. The mandated curriculum with "its origin outside the classroom, such as...the school district office” (Aoki, 1993, p. 257), represents the dominant notion of what people think of as the curriculum in school, a curriculum I found unsuited for the diversity of my students. Aoki (1993) encouraged me to move the mandated curriculum from its central position, and "give way to a more open landscape that offers possibilities by, in part, giving legitimacy to the wisdom held in lived stories of people” (p. 267). People's lived stories, their lived curricula, ought to shift toward a more central place in curriculum making where multiple perspectives co-compose lived curricula that resonate with lives of children and teachers. This shift in understanding curriculum making shaped how I positioned my research involving young struggling readers.

\section{Parents as Part of Curriculum Making}

My efforts to attend to students' stories (lived curricula) led me to pay attention to how their parents are involved in curriculum making in schools. Murphy and Pushor (2004) discussed the knowledge Murphy gained alongside his students’ parents, and how it made him understand the significant impact working closely with parents could have on his curriculum making. This realization changed his practice. He "shifted the living out of a unidirectional and hierarchical school agenda to the living out of an agenda in relationship with parents in reciprocally beneficial ways” (Murphy \& Pushor, 2004, p. 234). Murphy’s account draws my attention to how parents can influence, in parts, children's and teachers' lived curricula in school. This too, shaped my research puzzle as I began to consider parents' perspectives (their lived curricula) as they experienced their children's curriculum making in schools.

\section{Research Design}

\section{Methodology}

Experiences are the heart of learning, teaching, and living (Dewey, 1938). Drawing on Dewey's (1938) work, I understand learning and teaching to be relational, contextual, and influenced by the past, present, and future. Inquiring narratively (Clandinin \& Connelly, 2000) offers the possibility to attend to all aspects of education through an inquiry space shaped by the temporal, personal/social and place dimensions. Narrative inquirers study stories of experience nested in various milieus, times, and relationships in their organic form; this keeps "the wholeness of the life that produced [them]” (Downey \& Clandinin, 2010, p. 387). 
I came alongside my participants and entered their lives. They gradually shared their stories with me as we co-composed other stories and developed relationships. These relationships are fundamental "to what it is that narrative inquirers do" (Clandinin \& Connelly, 2000, p. 189); it is within those relationships that the inquiry lives and evolves, that field texts are co-constructed. The context of my study, the participants, and my research puzzles determined the different activities that compose my inquiry.

\section{Participants}

I met the participants at Ramsey Elementary School in a suburb of a Western Canadian city: $\underline{6}$ two boys, their mothers, one father, and their Grade 1 and Grade 2 teachers. In addition, the students from the Grades 1 and 2 classes were part of the study as they interacted with the primary participants. The boys at the centre of this study were chosen by their Grade 1 teacher because she identified them as struggling readers.

\section{Timeline}

My fieldwork started in May 2009 in the Grade 1 classroom. I visited the boys, their parents, and the two teachers during summer 2009. In September 2009, I joined the Grade 2 class and resumed classroom participation. By February 2010, I stopped classroom participation, but continued conversations with the mothers and boys. I will be negotiating research texts with the teachers. In this paper, I focus on one boy, Timmy.

\section{Field Texts}

The participants and I co-composed multiple kinds of field texts: field notes from classroom participation; transcripts of tape-recorded conversations with Timmy, his teachers, and his parents; drawings Timmy made during our talks; photographs Timmy took in the school; artifacts of Timmy's class work; pertinent school documents and my research journal. During the conversations I had with Timmy, and with his parents, they answered questions I prepared, but we also engaged in topics that emerged in the ongoing conversations. The story fragments presented here were composed either from the participants' words, or from my interpretation of the participants' recorded "actions, doings, and happenings, all of which are narrative expressions” (Clandinin \& Connelly, 2000, p. 79).

\section{Overview of the Time Spent at School}

I visited the Grade 1 class three mornings per week and familiarized myself with the class activities while helping students as needed. I gradually developed relationships with the children and teacher and learned about their lives. A few children seemed challenged with reading. Through numerous discussions, the teacher and I selected Timmy.

After meeting with Timmy's mother and gaining consent, I met with Timmy during class time, ${ }^{7}$ for 30 -minute sessions. At first, he was a little hesitant and shy, but quickly grew to look forward to coming "upstairs" with me..$^{-}$In June 2009, I had conversations with Timmy’s parents, and with the teacher. During the summer break, I visited the family and the Grade 1 teacher, and met the Grade 2 teacher who agreed to let me spend time in her classroom.

I resumed my in-class involvement in mid-September in the Grade 2 classroom, and continued conversations with Timmy, his Grade 2 teacher, and his mother. ${ }^{9}$ I also engaged in spontaneous conversations with Timmy's Grade 1 teacher when we met in the staffroom and had one recorded conversation with her. 


\section{Engaging With Field Texts}

\section{Transition From Field Texts to Research Texts}

I stopped visiting the school in February 2010, but continued to be in touch with Timmy and his parents. I began reading my various field texts that I had sorted by participants and document types during my fieldwork. I had numerous files of field texts including field notes from the classroom, transcripts of conversations with Timmy, with his parents, with his Grade 1 and Grade 2 teachers, Timmy's drawings, his photographs, school documents, and a research journal. Initially, I felt overwhelmed by the amount of field texts. I was unable to choose a file and start reading. I figured that if I read transcripts of conversations with Timmy, I would need to refer to the field notes written in the classroom on the days of the conversations to make sense of my reading. I thought I would need to go back and forth between different files in order to understand the contexts involved in my reading, and to appreciate the lived curricula of the participants. Finally, I decided to re-sort my field texts based on temporality, in monthly binders with everything in chronological order.

As I read field texts, I underlined every piece related to Timmy: What his teachers or parents said about him; what I said; what other children said. I transferred the information relating to Timmy to one document. The pulled-out pieces were listed one after the other as I temporally reviewed my notes. While doing that, I attended carefully to the different voices involved. It was important to identify clearly who said what, as I tried to interpret and analyze how everyone involved in the study constructed Timmy. I was also mindful of the three dimensional narrative inquiry space (time, place, and sociality). I read the pulled-out pieces many times and wrote notes next to some of them. I later decided to chunk my field texts in two temporal blocks: May to August 2009, and September 2009 to June 2010. The significant transition between Grade 1 and Grade 2 led to this specific chunking. In this manuscript, I share some of Timmy's experiences while he was in Grade 1.

The process of transitioning from field texts to research texts grew out of my efforts to make sense of my research field texts (data). I relied on my field texts to inform and guide my inquiry.

\section{Timmy}

Timmy was one of the smallest students in Grade 1. Born in January, most classmates were older than he was. Timmy's teacher often discussed potential participants. One day, she mentioned him: "Timmy is a January baby. He is not very strong” (S.T. Houle, personal communications, May 19, 2009). I began to pay attention to Timmy. During a reading activity, the teacher attended to a small group of students she identified as "weaker readers"; Timmy was part of that group. By June 2009, she suggested Timmy as a participant: "He feels the struggle. He is young” (S.T. Houle, personal communications, June 1, 2009). I was excited about the possibility of having Timmy as a participant. It was easy to feel attracted to him. He was talkative, sociable, and charming.

The teacher told me more about Timmy. She talked about his family, his older brother Luke, and his two parents with whom he lives. She believed Timmy's mother would gladly participate in my study, and would consent for her son to participate. I was starting to imagine them both as research participants. Fortuitously, Timmy started to befriend me; our relationship 
was developing well. I believed he would enjoy having conversations with me, and would want to be a participant.

\section{End of Grade 1 - Preparation for Grade 2}

For this article, I selected pieces from my field texts to share, as I believe they illuminate Timmy’s lived curriculum. This is part of a conversation with Timmy in June 2009.

Sonia: How do you get ready for Grade 1?

Timmy: You need to go to the store and get pencils, and get scissors, get glue Sonia: And do you have to get ready for Grade 2 now?

Timmy: Yeah!

Sonia: What do you have to do for that?

Timmy: You have to read chapter books if you want to.

Sonia: Ok.

Timmy: They're like, 70 pages and some are 800 pages.

Sonia: Wow!

Timmy: My brother's read 1000 pages. (S.T. Houle, personal communication, June 10, 2009)

This speaks of the shift Timmy experienced from transitioning between Grades 1 and 2, and of his home milieu that reveals his Grade 3 brother's competence in reading. Preparing for Grade 1 appears to have been more play and fun than what Timmy thought he needed to do in preparation for Grade 2. Many children experience shopping-for-supplies as a pleasant part of preparing for the new school year. Timmy did not mention shopping. He spoke of needing to learn to read chapter books like his brother did at the same age (personal communication, June 18, 2009). Timmy's brother's successful experiences with reading added a layer to how Timmy might have imagined Grade 2. Drawing on McCallister (2004), who points out that the "self emerges in part through imitative behaviour....We look to others to gain both a broader and keener sense of what is acceptable and possible" (p. 438). I wonder about how Timmy might have imagined his Grade 1 experience in regards to learning to read, as he followed in his brother's footsteps. Did he expect to learn to read in Grade 1, like his brother had? Did he think he was going to read chapter books, just as Luke did?

In the following, Timmy's mother recounts her son's reaction to the books she bought him for summer reading.

Mother: I know we had a hard time trying to find books for him to read, and just to keep at home because if you get picture books, they're really big words, they're not the smaller words....So I bought the Grade 1 summer reading pack. ${ }^{10}$ Well, it's all chapter books! He looked at it and he goes: MOM, Luke can have these.

Sonia: Is it like the Junie B. Jones series? $?^{11}$

Mother: Yeah, it's those kinds. It may be easy words but I think just the context of it being a chapter book scared him. I don’t want those right now mom. (S.T. Houle, personal communication, June 18, 2009)

Timmy's responses seemed to show a lack of confidence in his abilities, which made him a suitable study participant. 


\section{Representing Research Texts}

This research project's multiperspectival approach is represented in the following narrative verses I selected from my field texts. Timmy's remarks about reading, along with his mother's telling of his classroom experiences, his teacher's comments about his abilities, and my observations are put side by side in an attempt to represent Timmy's lived curriculum around learning to read, and how he was constructed by the adults around him.

\section{Narrative Verses}

\section{Grade 1, May-August 2009}

\section{Timmy}

I'm done home reading for the rest of the year.

I don't have to read anymore, I can just go out and play.

Reading is kind of difficult a little but not all the time. I like to read big words, not lots of small words.

Remember, I told you I do not like reading.

Sometimes, I like reading if it's big words, but if it's small words, I do not like reading.

If there's a lot of small words, you can't read that good cause you might need some glasses to see those.

I can see, but the doctor said I can't see that good. They said I can't really see that much, so I can't read that much small words.

Grade 2 will be more difficult. You know why? We read chapter books.

\section{Mother}

You'd see him get frustrated when they'd have to read something out and ... there's a few kids in the class that are very strong readers, and right from the get go. You could just tell by his expression "I can’t read that mom." You know, he just had that look on his face.

Guess the covered word; the teacher covers certain words. They had to read the sentence.

\section{Teacher}

Timmy struggles to read. Reading is hard work for now.

He is in the weaker readers' group. I gave him phonetics books. I control home reading for strugglers. Timmy is one of them.

I think his feeling about himself as a learner is just a little bit fragile.

I would tell his Grade 2 teacher, he needs some support to complete tasks and to, you know, in his writing, and reading.

He's not quite where you might want him to be at the beginning of Grade 2 . 


\section{Researcher}

Timmy often asks for my help in the classroom. He often needs my attention.

He asked for my help during computer time.

Timmy asked for my help to read and solve a math problem.

Timmy stopped by to say he needs help again.

Timmy came to sit with me during the writing activity.

Timmy was happy to have completed the reading requirements for the year, and was proud of his accomplishments. He also seemed relieved to have finished an activity he disliked, and sometimes found "kind of difficult." His comments about enjoying reading "big" words but not "lots of small words" show his awareness of the levels in reading materials, and I wondered if it shaped how he constructed himself as a reader. Timmy did not like reading "small words" because he found them too difficult. He mentioned the doctor said he "can't see that good." Might he be trying to justify why he could not read small words? Timmy envisioned Grade 2 as more difficult because he would have to read chapter books. Considering he did not like to read, particularly small words, I wondered how Timmy was anticipating Grade 2. Was he worried that he might not be "good enough" in Grade 2?

While she was in the classroom, Timmy's mother witnessed the struggle her son experienced. She saw how frustrated he was not to perform like his classmates, and wondered about such competitive activities. She also noticed him paired with a strong reader, and how that seemed to intimidate or discourage him, making him a quiet reading partner (not "good enough?"). Timmy’s mother knew about her son’s delay and tried not to worry about it. She did however, regularly ask the teacher what she could do to help him; she worried (S.T. Houle, personal communications, June 18, 2009). She, too, had started to construct him as "not good enough" and wanted to help "fix" what was "wrong" with him.

Mrs. Taylor, Timmy's teacher, made it clear he was not reading at grade level. Even though she attended to different levels of reading competency throughout her planned activities, Timmy was behind the expected reading level. To remedy that, she sent phonetics books home, and talked to his parents about his challenges (S.T. Houle, personal communications, June 12, 2009). Attempting to help Timmy speed up his reading development confirmed his delay. It was evident that, in Grade 1, the goal was to become a reader at a specific level. Why would there be intervention through phonetics books, if Timmy's reading level were not a problem? Why would Mrs. Taylor tell the Grade 2 teacher Timmy needs support? Why would she say he is not where she wants him to be?

The dominant narrative that children in Grade 1 need to learn to read has a serious impact on teachers' curriculum making. Timmy is being constructed by the mandated curriculum as not "good enough"; it is shaping how his parents and his teacher co-composed the lived curriculum with him. I doubt they are aware of that, and I imagine they would feel discomfort at how they were making curriculum if they were aware. I enjoyed helping Timmy, but his frequent need for support made me wonder about his confidence in completing tasks on his own. Why did he feel so strongly about asking for help? Did he feel incompetent? Was the mandated curriculum also shaping how Timmy constructed himself as not "good enough"? How will this experience live on, in his further experiences (Dewey, 1938)? 


\section{Closing Reflections}

As educators read my work, I hope they will start to name themselves as curriculum makers and imagine their work with children and their families differently. Perhaps these stories of Timmy, that speak of his lived curriculum, will inspire them to become curriculum makers who see big (Greene, 1995), that is, who see children as human beings, as whole in their integrity. Greene distinguishes seeing big from seeing small which can be understood as looking from the vantage point of the system, without considering the lives of the students (Clandinin et al., 2006). As a curriculum maker, I see small when I pay attention only to the mandated curriculum. I see the trends, patterns, factors and outcomes; I do not see lives. Curriculum makers need to attend to the stories and lives (lived curricula) of their students, of their students' parents, and their own (Clandinin et al., 2006), and make these the starting point of curriculum making.

Teachers who decentre the mandated curriculum in favour of moving children's lived curricula to a more central position still attend to the mandated curriculum but do it differently. In so doing, they experience tensions, as they are pulled in different directions. Making curriculum, a co-composition involving multiple lives, is not simple. That is part of making curriculum with human beings; it needs to be recognized and discussed. There cannot be one curriculum for all if teachers are to negotiate lived curricula with children and families, considering lives, contexts, temporality, and relationships. While expectations and mandates exist, they need not be the starting point for curriculum making; lives should. What might school look like for Timmy if curriculum was made considering his abilities and previous experiences, rather than his inability to perform according to the mandated curriculum? How might Timmy construct himself in that situation? Might he be "good enough"? Would he make the grade? What if what mattered most in the classrooms were the lives and experiences of the children, rather than the mandated curriculum? 


\section{References}

Alberta Education.(2000). English language arts (K-9). Retrieved from http://education.alberta.ca/media/450519/elak-9.pdf

Aoki, T. (1993). Legitimating lived curriculum: Towards a curricular landscape of multiplicity. Journal of Curriculum and Supervision, 8(3), 255-268.

Clandinin, D. J., \& Connelly, F. M. (1996). Teachers’ professional knowledge landscapes: Teacher stories - stories of teachers-school stories - stories of schools. Educational Researcher, 25(3), 24-30.

Clandinin, D. J., \& Connelly, F. M. (2000). Narrative inquiry: Experience and story in qualitative research. San Francisco, CA: Jossey-Bass Publishers.

Clandinin, D. J., Huber, J., Huber, M., Murphy, M. S., Murray-Orr, A., Pearce, M., \& Steeves, P. (2006). Composing diverse identities: Narrative inquiries into the interwoven lives of children and teachers. New York, NY: Routledge.

Connelly, F. M., \& Clandinin, D. J. (1988). Teachers as curriculum planners: Narratives of experience. New York, NY: Teachers College Press.

Dewey, J. (1938). Experience and education. New York, NY: Collier MacMillan Publishers.

Downey, C. A., \& Clandinin, D. J. (2010). Narrative inquiry as reflective practice: Tensions and possibilities. In N. Lyons (Ed.), The handbook of reflection and reflective inquiry (pp. 385400). New York, NY: Springer.

Greene, M. (1995). Releasing the imagination: Essays on education, the arts, and social change. San Francisco, CA: Jossey-Bass Publishers.

McCallister, C. (2004). Schooling the possible self. Curriculum Inquiry, 34(4), 425-461.

Murphy, B., \& Pushor, D. (2004). Parent marginalization, marginalized parents: Creating a place for parents on the school landscape. Alberta Journal of Education, 50(3), 221-232.

\section{Endnotes}

1 Specific 'outcome statements' (expected by the end of each grade) in the Grade 1 Alberta Language Arts Program of Studies (Alberta Education, 2000, p. 22) indicate that reading is to be achieved in Grade 1.

$\underline{2}$ Struggling readers in this study are children who were identified as delayed readers by their Grade 1 teacher. The delay in learning to read refers to time, to what is expected from within our sociocultural and institutional narratives. I did not do any diagnostic testing and do not refer to disabilities.

$\underline{3}$ Though curriculum developers at Alberta Education may develop the Programs of Studies, and lay them out as recommendations, when they reach the school level, they are often experienced by teachers as mandated.

4 "Sacred stories" of school refer to the ways dominant theoretical stories are assumed to drive practice in schools and to shape the lived stories of the people who live on the school landscape. 
They are said to have the quality of sacred stories, as they are often unquestioned (Clandinin \& Connelly, 1996).

$\underline{5}$ While there are multiple ways to look at curricula in schools, for the purpose of this study, I only refer to the mandated and the lived curricula.

$\underline{6}$ The school's name and the participants' names are pseudonyms.

${ }^{7}$ My plan was to meet with Timmy during the lunch hour, but on the teacher's prompting, we met during class time.

$\stackrel{8}{ }$ The conversations I had with Timmy took place on the school's second floor, in a small room adjacent to the library.

9 Specifically, I had bi-monthly recorded conversations with Timmy, two recorded conversations with the Grade 2 teacher between September 2009 and February 2010, as well as numerous exchanges with her during spare time. From September to February, I met Timmy's mother on four occasions for about one hour.

$\underline{10}$ Publishing companies send flyers to schools to give to parents to buy books for their children. At the end of the year, they suggest collections of books for specific grade levels that are called "summer reading packs."

$\underline{11}$ The Junie B. Jones series is a series of junior chapter books with an average of 70 pages per book. 